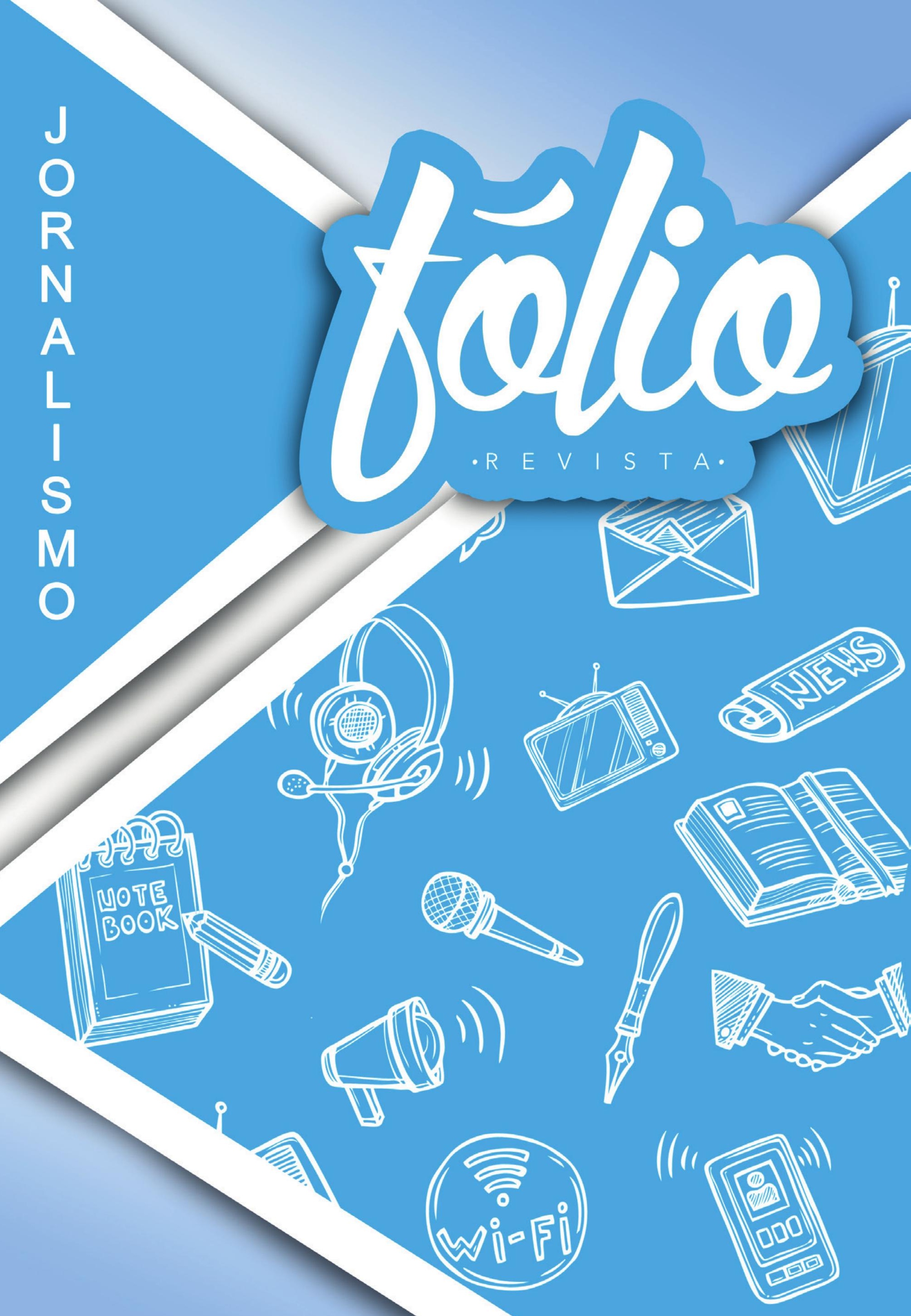




\title{
Impeachment da presidente Dilma: uma análise das capas das revistas Carta Capital e Veja ${ }^{1}$
}

\author{
Juliana de Miranda Villeroy² \\ Valéria Deluca Soares ${ }^{3}$
}

\section{Resumo}

O objetivo geral deste estudo é analisar como as revistas Carta Capital e Veja abordaram o impeachment de Dilma Rousseff nas capas das edições publicadas em 6 de abril e 18 de abril de 2016, respectivamente, considerando os conceitos de escândalo político. As influentes opiniões políticas dessas duas publicações justificam uma análise das suas capas a respeito de uma das maiores crises envolvendo corrupção no Brasil nos últimos anos. Por meio de uma pesquisa descritiva e exploratória, de abordagem qualitativa, usa-se a análise de conteúdo, a partir das categorias poder, reputação e confiança, baseadas na Teoria Social do Escândalo (THOMPSON, 2002). Verificou-se que não houve imparcialidade na divulgação do evento ao público, por parte das capas das duas revistas. O conteúdo de ambas parece ter se baseado essencialmente, em análises e opiniões dos próprios veículos, o que contempla a hipótese deste estudo de que as duas publicações teriam sido parciais, sendo a Carta Capital alinhada à esquerda e a Veja à direita.

Palavras-chave: Jornalismo Político. Jornalismo de Revista. Impeachment de Dilma Rousseff. Escândalo Político. Revistas Veja e Carta Capital.

\section{Abstract}

The general objective of this study is to analyze how the magazines Carta Capital and Veja dealt with the impeachment of Dilma Rousseff in the covers of the issues published on April 6 and April 18, 2016, considering the concepts of political scandal. The influential political opinions of these two publications justify an analysis of their cover on one of the major crises involving corruption in Brazil in recent years. By means of a descriptive and exploratory qualitative approach, the content analysis, based on the categories of power, reputation and trust, based on the Social Theory of Scandal (THOMPSON, 2002), is used. It was verified that there was no impartiality in the disclosure of the event to the public, by the two magazines. The content of both seems to have been based essentially on analyzes and opinions of the vehicles themselves, which contemplates the hypothesis of this study that the two publications would have been partial, with the Carta Capital aligned to the left and Veja to the right.

Keywords: Political Journalism. Journalism Journal. Impeachment of Dilma Rousseff. Political scandal. Magazines Veja e Carta Capital.

\footnotetext{
1 Artigo resultante da monografia realizada, por Juliana de Miranda Villeroy, para obtenção do título de Bacharel em Jornalismo, junto ao Centro Universitário Metodista IPA, no segundo semestre de 2017.

2 Estudante de Jornalismo no Centro Universitário Metodista IPA. Encarregada da Seção de Comunicação e Redes Sociais da Prefeitura Municipal de Guaíba. Contato: villeroyjuliana@gmail.com

3 Doutora em Comunicação Social. Jornalista. Professora do Centro Universitária Metodista IPA. Contato: valeriadeluca@hotmail.com
} 


\section{Introdução}

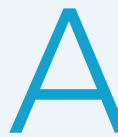

crise política que se instalou no Brasil em 2015, trouxe à tona disputas partidárias e investigações de corrupção sem precedentes. Um dos acontecimentos marcantes foi o pedido de impeachment da então presidente da República, Dilma Rousseff. O momento era de protestos nas grandes cidades, com ataques inclusive aos veículos de comunicação. Em menos de um ano, o resultado desse cenário foi a aprovação do processo de impeachment e a destituição de Dilma do cargo de presidente. Segundo o site do $\mathrm{G}^{14}$, as acusações se basearam em crimes de responsabilidade por pedaladas fiscais e por créditos suplementares sem autorização legislativa.

Durante o primeiro governo de Dilma, a presidente tomou uma série de medidas contundentes, como modificações em concessões, redução das taxas de juros e demissão de ministros envolvidos em corrupção. Conforme explica Eduardo Costa ${ }^{5}$, em artigo publicado pela Universidade Federal do Rio de Janeiro, Dilma parecia querer enquadrar os políticos, os partidos e o Congresso Nacional. Em comparação com o ex-presidente Lula, do mesmo partido, Dilma adotou uma postura diferente. Se mostrava firme, de opinião forte e não muito engajada politicamente. Enquanto Lula articulava cada passo e usava do poder político para barganhar ações e programas.

Segundo Costa, Dilma se mostrou um desastre no que tange à habilidade política. Sem capacidade de dialogar, até mesmo com deputados e senadores do seu partido, o governo foi perdendo votações. Na campanha de reeleição, a candidata adotou um discurso mais popular. Direcionava-se aos segmentos mais pobres e aos movimentos sindicais. Desde o começo do segundo mandato, a presidente enfrentou a rejeição e dificuldades com a oposição e aliados. A crise po-

4 SITE G1. Processo de Impeachment de Dilma. Disponível em <http://g1.globo.com/politica/processo-de-impeachment-dedilma/ > . Acesso em: 18 de junho de 2017

5 DILMA: de "coração valente" à "presidenta acuada". Disponível em: <http://www.ie.ufrj.br/intranet/ie/userintranet/hpp/ arquivos/170820154652_ArtigodeOpinioDilma....16.08.2015.pdf> Acesso em: 26 de setembro de 2017. lítica atingiu seu ápice quando o vice-presidente Michel Temer convocou a imprensa e reconheceu que a situação era grave. Além disso, conforme noticiado pela Folha de São Paulo ${ }^{6}$ Temer divulgou uma carta, escrita por ele, direcionada à presidente Dilma em que se mostrava insatisfeito com a conduta adotada por ela.

O acontecimento pode ser caracterizado por momento de crise econômica e política e de baixa popularidade da presidenta. Segundo o Portal Planalto ${ }^{7}$, Dilma, no início, contava com ampla base aliada do Congresso, o que foi diminuindo ao longo do julgamento. Além disso, ela teve forte apoio de movimentos sociais e de organizações sindicais, como a Central Única dos Trabalhadores (CUT), que organizou manifestações contrárias ao impedimento.

O processo de afastamento teve início em 02 de dezembro de 2015, quando o ex-presidente da Câmara dos Deputados, hoje ex-deputado, Eduardo Cunha deu prosseguimento ao pedido dos juristas Hélio Bicudo, Miguel Reale Júnior e Janaína Paschoal. Como noticiado no site do $\mathrm{G} 1^{8}$, o caso teve duração de 273 dias e se encerrou em 31 de agosto de 2016, tendo como resultado a cassação do mandato, mas sem a perda dos direitos políticos de Dilma.

Todo o processo e ações decorrentes dessa crise política caracterizam um escândalo político. Os escândalos políticos constituem uma das principais matérias-primas do jornalismo político moderno. Na esfera política, em geral, os escândalos estão associados à corrupção e ao suborno. No caso do Brasil, malversação de recursos, desvios de dinheiro, compra de votos, financiamento de campanhas com caixa 2, favorecimentos em licitações e apadrinhamentos no serviço público, entre outras ações do tipo, constituem os princi-

6 FOLHA DE SÃO PAULO. Em carta desabafo a Dilma, Temer diz que foi desprezado. Disponível em: <http://www1.folha.uol.com. br/poder/2015/12/1716259-em-carta-desabafo-a-dilma-temer-dizque-foi-desprezado.shtml>. Acesso em: 28 de setembro de 2017.

7 Portal Planalto. Trajetória da presidenta Dilma Rousseff. Disponível em: <http://www.brasil.gov.br/governo/2015/01/ conheca-a-trajetoria-da-presidenta-dilma-rousseff $>$. Acesso em: 11 de junho 2017.

8 SITE G1. Disponível em: <http://g1.globo.com/politica/processode-impeachment-de-dilma/ > . Acesso em: 18 de junho de 2017. 
pais elementos dos escândalos explorados pelo Jornalismo.

A partir deste cenário, o presente trabalho apresenta como tema a análise das capas de duas revistas nacionais: Carta Capital e Veja. As revistas se caracterizam pela especialização, periodicidade e formato físico. Cada revista possui um tipo de público definido e tem como premissa dialogar com esse perfil. Revistas são veículos amplificadores, capazes de confirmar, explicar e aprofundar histórias veiculadas por mídias mais imediatas. Pode-se caracterizá-las por recrear, trazer análise, reflexão e experiência de leitura. Em função da periodicidade, têm mais tempo para elaborar a pauta, checar e analisar informações, explorar diferentes ângulos, aprofundar o tema e ajustar 0 foco ao leitor. As reportagens assumem caráter de recuperação dos acontecimentos para construção de textos interpretativos.

O cenário nacional disponibiliza diversificadas revistas. A Veja é uma revista de distribuição semanal da editora Abril, criada em 1968. Apesar de não ser explícito, pode-se inferir que o periódico segue uma linha editorial alinhada à direita. Observa-se esse aspecto principalmente na editoria de política, com o enaltecimento de políticos afiliados à ala direitista9. Em contraposição, a Carta Capital foi criada, em 1994, como uma alternativa às revistas dominantes no mercado da época, Isto é e Veja. Hoje, assume uma postura, em grande parte, de análise crítica. A linha editorial da revista é assumidamente esquerdista ${ }^{10}$.

\footnotetext{
9 A Direita trabalha pela liberdade individual. Estão inseridos na Direita conservadores, democratas-cristãos, liberais e nacionalistas, e ainda o nazismo e fascismo na chamada Extrema Direita. A Direita procura manter a livre iniciativa de mercado e os direitos à propriedade privada. Quanto às questões morais, assume a defesa da família tradicional e pena de morte a presos por crimes hediondos. Disponível em <http://dagobah.com.br/wp-content/ uploads/2017/01/BOBBIO-Norberto-1994-Direita-e-esquerdaRaz\%C3\%B5es-e-significados-de-uma-distin\%C3\%A7\%C3\%A3opol\%C3\%Adtica.pdf>. Acesso em: 05 de novembro de 2017

10 A Esquerda brasileira, na teoria, defende a justiça social. Inseridos na Esquerda há os social-democratas, progressistas, socialistas democráticos e ambientalistas. A Esquerda prega uma economia mais justa e solidária, com maior distribuição de renda. Quanto às questões morais, defende temas como aborto, casamento gay e legalização da maconha. Disponível em <http://dagobah.com.br/wp-content/ uploads/2017/01/BOBBIO-Norberto-1994-Direita-e-esquerdaRaz\%C3\%B5es-e-significados-de-uma-distin\%C3\%A7\%C3\%A3opol\%C3\%ADtica.pdf> Acesso em: 05 de novembro de 2017
}

Nesse contexto, a presente pesquisa apresenta uma análise das capas das edições 895 da Carta Capital e 2474 (edição especial) da Veja. A Carta Capital traz em sua capa uma comparação do Brasil atual com o de 1964, ano do chamado Golpe de Estado. Por sua vez, a revista Veja retrata a comemoração da população, com o rosto pintado de verde e amarelo e vestindo a camiseta da Seleção Brasileira de Futebol.

Assim, o tema de estudo concentra-se no jornalismo de revista e no escândalo político. E, tem por delimitação o estudo das capas indicadas anteriormente. Logo, o problema de pesquisa que vai balizar o estudo é: de que forma as revistas Carta Capital e Veja abordaram o impeachment de Dilma Rousseff em suas capas, veiculadas, respectivamente, nos dias 6 de abril e 18 de abril de 2016, considerando os conceitos de escândalo político?

Parte-se do pressuposto que cada um dos periódicos citados apresenta distintos discursos. Cabe, então, uma reflexão quanto às informações e ideologias apresentadas pelas revistas e uma contextualização do momento político pelo qual passava o país, ligando ao modo como a Veja e a Carta Capital se posicionaram diante do processo de impeachment. Entende-se que a Veja apresenta um discurso alinhado à direita, com manchetes e capas que seguem este mesmo princípio. A Carta Capital, por sua vez, assumidamente esquerdista, traz material geralmente ligado ao PT e aliados.

Nesse sentido, observa-se que a Veja trouxe uma visão mais ligada à oposição, mostrando os protestos a favor do impeachment e personalidades que representam a Direita. E, a Carta Capital procurou apresentar o discurso petista do golpe, conectando os fatos dos protestos e do processo com o golpe de Estado de 1964.

O objetivo geral deste estudo passa a ser então, analisar como as revistas Carta Capital e Veja abordaram o impeachment de Dilma Rousseff nas capas das edições publicadas em 6 de abril e 18 de abril de 2016, considerando os conceitos de escândalo político. São objetivos específicos: conceituar e caracterizar o jornalismo de revista, com ênfase nos aspectos que compõem a capa; apresentar e caracterizar o escândalo político; contextualizar o momento político e econômico 
pelo qual passava o Brasil após a reeleição de Dilma Rousseff, em 2014, até o momento do impeachment; apresentar a linha editorial das revistas Carta Capital e Veja; e observar como as duas revistas retrataram o impeachment de Dilma Rousseff, a partir do conceito de escândalo político.

A presente pesquisa pretende despertar o interesse público para a discussão sobre como a imprensa aborda os problemas e os escândalos políticos do Brasil. No Brasil, segundo dados corroborados pela Secretaria de Comunicação Social da Presidência da República ${ }^{11}$, cerca de $58 \%$ da população brasileira confia totalmente nas informações divulgadas pelos veículos de comunicação. O mesmo estudo revela que a confiança do receptor aumenta quando relacionada aos periódicos, como jornais e revistas. Dessa forma, surgiu o interesse em trabalhar o estudo a partir de duas revistas de renome no Brasil, a Veja e a Carta Capital, para entender como disseminam as notícias e cativam o público. As duas são conhecidas por abordarem temas ligados à política, sempre assumindo um posicionamento, no entendimento da pesquisadora, uma contrária à outra.

Além disso, o estudo pretende auxiliar quanto ao entendimento sobre o posicionamento ideológico e político dos jornalistas em revistas. Para os profissionais deste segmento, é importante e pertinente o debate para que se possa entender como os veículos trabalham a imparcialidade e de que forma expressam opiniões.

A condição de isento, imparcial, garante ao jornalista e ao seu trabalho, uma espécie de selo de garantia do produto notícia. Com este estudo, pretende-se pontuar os princípios do jornalismo, tornando este um objeto de pesquisa para outros trabalhos nesta área. O debate quanto aos princípios da imparcialidade também é um dos objetivos do presente trabalho. Os profissionais de jornalismo lidam com o conceito de isenção diariamente na produção de cada matéria. Sabe-se que os donos de jornais, editores e fontes cobram cer-

\footnotetext{
11 Secretaria de Comunicação Social da Presidência da República. Pesquisa brasileira de mídia. Disponível em: <http://www.secom. gov.br/atuacao/pesquisa/lista-de-pesquisas-quantitativas-equalitativas-de-contratos-atuais/pesquisa-brasileira-de-midiapbm-2015.pdf>. Acesso em: 18 de novembro de 2017.
}

to posicionamento do profissional, uma vez que têm interesses em comum. Sabendo disso, esta pesquisa pretende ampliar a visão a respeito dos posicionamentos das revistas Veja e Carta Capital.

Dito isto, indica-se que este trabalho se caracteriza por ser uma pesquisa de caráter descritivo-exploratório, em uma abordagem do tipo comparativa, conforme Gil (1989; 2007). Nesta linha, a natureza da pesquisa é qualitativa, de acordo com Vergara (2007); André (1983) e Fernandes (1991). As técnicas de coleta utilizadas na pesquisa são a pesquisa bibliográfica, a pesquisa documental e a observação simples das capas selecionas, segundo Fonseca (2002), Gil (1989) e Moreira (2004). Para a apresentação, análise e interpretação dos dados, utiliza-se a análise de conteúdo (BARDIN, 1977).

\section{A análise das capas}

A análise se baseia nos elementos de um escândalo político, apresentados na Teoria Social do Escândalo, proposta por Thompson (2002). São eles o poder, a reputação e a confiança. Essa teoria pode ser formulada pelo seguinte enunciado: "escândalos são lutas pelo poder simbólico em que a reputação e a confiança estão em jogo" (THOMPSON, 2002, p. 296). Não é regra que escândalos destruam a reputação e enfraqueçam a confiança, mas eles os potencializam.

Para verificar de que forma as revistas Carta Capital e Veja abordaram o impeachment de Dilma Rousseff em suas capas, veiculadas, respectivamente, nos dias 6 de abril e 18 de abril de 2016, considerando os conceitos de escândalo político, usa-se como categorias de análise os elementos da Teoria Social do Escândalo (THOMPSON, 2002). Assim as categorias poder, reputação e confiança conduzem a análise de conteúdo das capas.

Inicialmente, as duas capas são descritas, contemplando a proposta de pesquisa descritiva. Neste momento, analisa-se os elementos, imagens e textos, que compõem a capa. Após, a partir das categorias elencadas, cumpre-se plenamente a pesquisa exploratória, com a análise dos dados, feita com o suporte do referencial teórico. 
E, então, são trazidas as inferências da pesquisadora, contemplando a interpretação dos dados, com vista a responder o problema da pesquisa.

\section{Brasil, 19642016 (Carta Capital, ed. 895, abril. 2016)}

FIGURA 1 - Capa da Carta Capital ed. 895 de 6 de abril de 2016

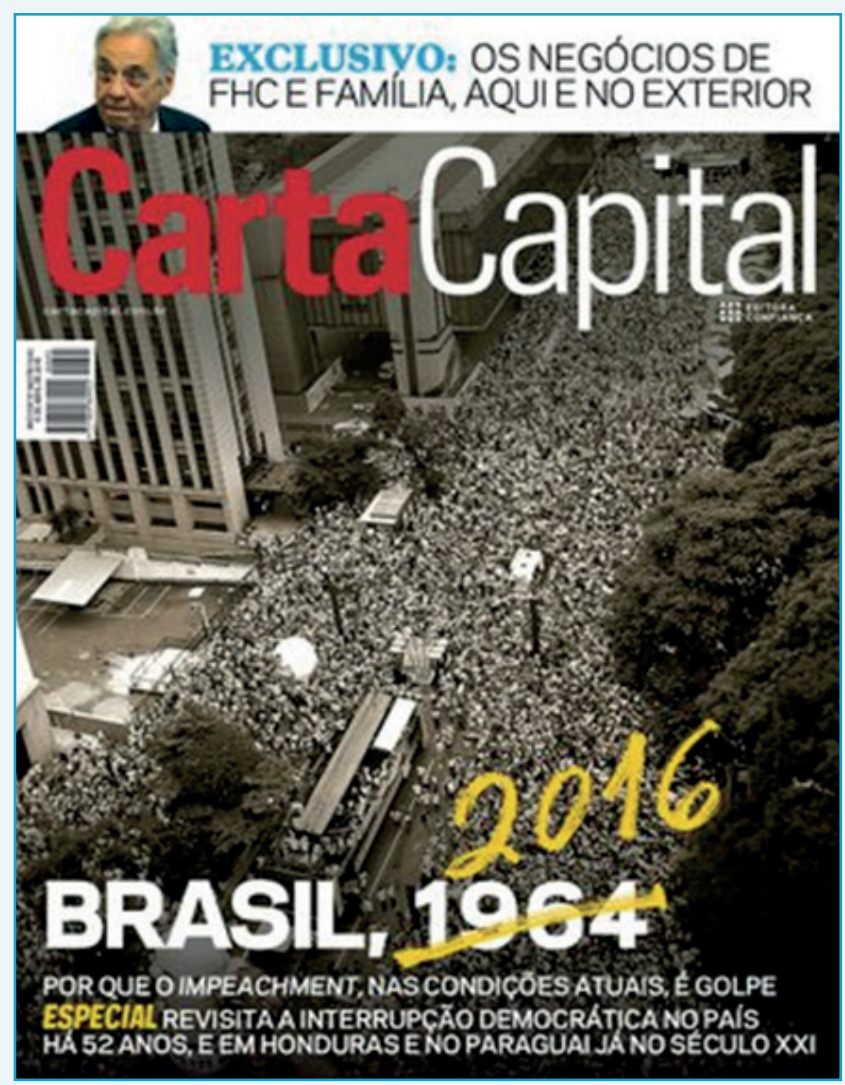

Fonte: Site da Carta Capital

A capa da edição da Carta Capital (FIGURA 1) faz uma referência ao chamado Golpe de Estado de 1964. Na época, o golpe militar foi saudado por importantes setores da sociedade brasileira. Conforme os documentos do Centro de Pesquisa e Documentação de História Contemporânea do Brasil ${ }^{12}$, grande parte do empresa-

12 Centro de Pesquisa e Documentação de História Contemporânea do Brasil. Disponível em: <http://cpdoc.fgv.br/ producao/dossies/Fatos/magens/Golpe1964>. Acesso em: 21 outubro 2017 riado, da imprensa, dos proprietários rurais, da Igreja Católica, vários governadores de estados importantes e amplos setores da classe média pediram e estimularam a intervenção militar. $\bigcirc$ objetivo, o mesmo apontado nos protestos pró-impeachment de Dilma em 2016 ${ }^{13}$, era pôr fim à ameaça de esquerdização do governo e de controlar a crise econômica.

A manchete 'Brasil, 1964 2016' faz uma comparação entre o golpe militar de 1964 e o processo de impeachment de Dilma em 2016. Desta forma, a empresa jornalística em questão traz uma afirmação e uma visão própria do acontecido. Não deixa possibilidade de dúvida sobre a ilegalidade do processo. Os ideais e objetivos da Carta Capital são deixados de forma clara para os leitores, demonstrando a insatisfação e indignação perante o acontecido.

A linha de apoio 'Por que o impeachment, nas condições atuais, é golpe', aparece como forma de complemento à manchete e reforça a ideia de ilegalidade do pedido de impeachment. Destaca-se a ideia passada pela Carta em 'nas condições atuais', que remete ao processo de impeachment, apoiado pelo PT, do presidente Fernando Collor, em $1992^{14}$. Na época, o PT era o mais ferrenho defensor do impedimento do presidente Fernando Collor de Mello, no período do PRN (Partido da Reconstrução Nacional), e discursava para pedir a saída do chefe do Executivo e rechaçar duramente a ideia de que se tratava de um golpe.

Além disso, a capa traz um enunciado para uma matéria sobre os golpes de estado no Brasil, Honduras e Paraguai, em que aparecem como uma possível tentativa de influenciar o público a acreditar nas teorias da Carta. Cabe lembrar que em março de 1964, foi deflagrado um golpe militar contra o governo legalmente constituído de João Goulart. A falta de reação do governo e dos grupos que lhe davam apoio resultou no fracasso, ao não conseguirem montar uma greve geral

13 El País. Ditadura Militar: quem pede a volta sabe o que é?. Disponível em: <https://brasil.elpais.com/brasil/2015/04/01/ opinion/1427860120_903017.html> Acesso em: 21 outubro 2017

14 POLITIZE. Por que Collor sofreu impeachment. Disponível em: <http://www.politize.com.br/impeachment-collor-porque-sofreu/> Acesso em: 29 de outubro de 2017. 
proposta pelo Comando Geral dos Trabalhadores (CGT) em apoio ao governo. Nos primeiros dias após o golpe, uma violenta repressão atingiu os setores politicamente mais mobilizados à esquerda no espectro político. Milhares de pessoas foram presas de modo irregular, e a ocorrência de casos de tortura foi comum, especialmente no Nordeste. ${ }^{15}$

Honduras viveu momentos conturbados quando se trata de política. Ao longo de sua história, o país sofreu cinco golpes militares que destituíram o governo vigente, em 1956, 1963, 1972, 1978 e $2009^{16}$. O último caso, em 2009, em que a Carta Capital17 já se referiu outras vezes, comparando-o com o Brasil, foi destituído o presidente Manuel Zelaya Rosales. O golpe não apenas gerou uma grave quebra da ordem constitucional, mas também fez com que a economia e a institucionalidade do país colapsassem, ilhando-o internacionalmente e fraturando a sociedade hondurenha.

O golpe no Paraguai é um dos mais recentes, aconteceu em $2012^{18}$. O veloz processo de impeachment contra o presidente paraguaio Fernando Lugo resultou na sua substituição pelo então vice-presidente, Frederico Franco, que um ano antes havia rompido coligação com Lugo. As primeiras medidas de Franco no governo buscaram restabelecer a ordem tradicional. Substituiu e perseguiu todos os funcionários nomeados por Lugo e abriu caminho a uma dita modernização agrícola reivindicada pelos latifundiários por meio da imprensa. A comunidade internacional condenou a deposição de Lugo e suspendeu o Paraguai da

15 Centro de Pesquisa e Documentação de História Contemporânea do Brasil. Disponível em: <http://cpdoc.fgv.br/ producao/dossies/Fatoslmagens/Golpe1964>. Acesso em: 21 outubro 2017

16 BBC. Disponível em: <http://www.bbc.com/portuguese/ noticias/2009/07/090702_hondurastimeline> Acesso em: 30 de outubro de 2017

17 Carta Capital. Honduras e Paraguai: motivo de inspiração. Disponível em: <https://www.cartacapital.com.br/revista/895/ honduras-e-paraguai-motivos-de-inspiracao> Acesso em: 30 de outubro de 2017

18 Brasil de Fato. Disponível em: <https://www.brasildefato.com br/2017/04/04/pos-golpe-movimentos-do-paraguai-e-hondurastentam-fortalecer-a-resistencia-popular/>. Acesso em: 30 de outubro de 2017
Unasul e do Mercosul, enquanto não retornasse um mandatário democraticamente eleito. Além disso, vários países no mundo desconheceram o novo governo e provocaram um isolamento internacional que prejudicou gravemente a situação do país.

Outra informação da capa, uma chamada, destacada pela palavra 'Exclusivo', destaca uma reportagem sobre os negócios do ex-presidente Fernando Henrique Cardoso e família. Conteúdo exclusivo é um aspecto fundamental para os veículos de comunicação. Nesse sentido, a Carta, com o título 'Exclusivo', tenta passar a ideia de credibilidade da empresa em ter conseguido um conteúdo especial para aquela edição. Também traz o entendimento de que se trata de uma descoberta sobre o ex-presidente e sua família, algo que nenhum outro veículo abordou.

Quanto às imagens da capa, ao fundo apresenta uma das manifestações pró-impeachment na Avenida Paulista, em São Paulo. A foto aparece em tons de preto e branco. Entende-se que a proposta é relacionar a imagem com os enunciados e com o conteúdo da reportagem, que trata como um 'período obscuro'. A capa vem em cores branca, vermelha e amarelo, as mesmas presentes na logo do Partido dos Trabalhadores (PT). Acredita-se que o posicionamento é claramente contra o impeachment.

As cores têm a capacidade de transmitir emoções e estimular sentimentos. Diante disso, pretende-se expor o significado das cores utilizadas pela Carta Capital e o que elas provocam no leitor. Segundo o Dicionário dos Símbolos19, a cor Amarelo simboliza brilho, vida e esclarecimento e, além de refletir descontração, também pode simbolizar a covardia ou inveja. O Branco é uma cor positiva, símbolo da rendição e da paz. É a cor de luto na China, Índia e no Japão, e originalmente também era na Europa. O Preto simboliza o mau, especialmente pelo fato de representar ausência de cor. Representa o submundo, mas originalmente é associado à autoridade. Por fim, o

19 Dicionário dos Símbolos. Disponível em: <https://www. dicionariodesimbolos.com.br/significado-cores/>. Acesso em: 05 de novembro de 2017. 
vermelho é uma cor estimulante, simboliza coragem, juventude, criatividade e desejo. $\bigcirc$ vermeIho escuro representa guerra e perigo.

Apesar da utilização das cores ser algo que pode ser visto como leviano ou não intencional, observa-se que nada é usado por acaso quando se trata de um escândalo político e de influenciar a população. Dessa forma, percebe-se que a objetividade é realmente deixada de lado, a fim de conquistar o público-alvo e fazer com que adotem determinada linha de pensamento.

Conforme Amaral (1996), o conceito de objetividade foi adotado pelo jornalismo no século XIX, quando, notou-se a necessidade de distribuição da notícia para alimentar os mais diferentes mercados: político, econômico e social, mas também que tivesse alcance geográfico mais extenso. Alcançar a objetividade significaria então, ser isento, imparcial em sua descrição sobre o acontecimento. Ficou decidido que a notícia guardaria isenção e apareceria em sua forma crua, natural, sem interpretação.

Observa-se que a proposta da Carta Capital foge completamente a esse princípio norteador do Jornalismo. A revista faz afirmações, se posiciona de um lado da crise e ainda traz possíveis soluções e o que deveria ser feito. Destaca-se que não há margens para interpretação do leitor, apenas afirmações.

Desse modo, ressalta-se que as observações se encaixam na definição de gênero interpretativo de Melo (2003) e Campos (2009). Grande parte dos estudiosos acreditam que o gênero interpretativo é a análise de fatos divulgados e o diferenciam do relato puro da informação. Melo (2003) explica que a construção de uma informação dentro do gênero oscila entre o informativo e o opinativo. E permite, segundo Campos (2009), maior liberdade quanto a sua abordagem. Um dos riscos do gênero interpretativo é subordinar a informação a crenças e teorias não comprovadas, transformando-a em opinião.

Conforme as definições de gênero interpretativo, observa-se que essa tendenciosidade é trazida pela capa desta edição da Carta Capital. A empresa se posiciona, mistura informação (o processo de impeachment) com opinião (o impeachment ser considerado golpe).
O estilo de redação das revistas, segundo $\mathrm{Vi-}$ las Boas (1996), não combina com a imparcialidade mítica dos veículos informativos, pois, todo o texto, em especial o interpretativo, carrega consigo uma intenção, uma tendência consonante com a inclinação de seus leitores. Sendo assim, considerando que os leitores da revista Carta Capital politicamente apoiam a Esquerda, verifica-se que a intenção da revista é mostrar o impeachment como golpe, assumindo esta como uma única verdade. Segundo Scalzo (2004), mais do que um meio de comunicação a revista é uma marca. Por isso, a tendência da Carta é de vender uma ideia e fazer com o público a compre.

O foco em determinado público faz com que a revista, além de informar, estampe um status e classifique o seu leitor. Os filtros ideológicos estão presentes nas etapas do processo produtivo de uma notícia, desde a escolha do que será ou não divulgado, passando pelo enfoque que será dado, como será pesquisado, quem ganhará voz dentro do veículo, até a edição do que foi apurado. $\bigcirc$ ângulo dado por uma pauta é definido por um seleto grupo dentro da redação, que são pessoas ligadas aos interesses ideológicos e comerciais da empresa. Como constatado através da descrição da capa da Carta Capital, a revista contém exatamente essas características de parcialidade e de posicionamento ideológico e comercial. Carta Capital mantém este posicionamento ligado à Esquerda e reforça um discurso pró-PT.

É de conhecimento da sociedade que os veículos de comunicação exercem forte influência na opinião pública. Diante dessa realidade, parte a premissa de que o jornalismo constitui o Quarto Poder. Conforme Bonelli (1996), a narrativa jornalística interfere na escolha dos temas e aspectos que serão destacados nos debates políticos. Tendo como exemplo a forma como a Carta Capital abordou o processo de impeachment, o definindo como golpe, verifica-se que a afirmação é exercida na prática. Após a cobertura, manifestantes contra o impeachment começaram a utilizar da ideia de que Dilma estava sofrendo um golpe.

Como constatou-se com a análise das informações contidas na capa, a técnica utilizada pela Carta não condiz com as afirmações de Martins (2005). O autor destaca que, com o passar dos 
anos, informar se tornou a maior preocupação em uma cobertura, ao contrário do que acontecia antes em que a intenção era convencer o leitor a adotar uma ideia. A empresa age de forma contrária, levando a opinião do veículo como se fosse a única face do acontecimento, fazendo o leitor acreditar que deve assumir uma mesma postura diante dos fatos.

\section{Impeachment: SIM 367x146 NÃO (Veja, ed. especial 2474, abril. 2016)}

FIGURA 2 - Capa da Veja ed. especial 2474 de 18 de abril de 2016

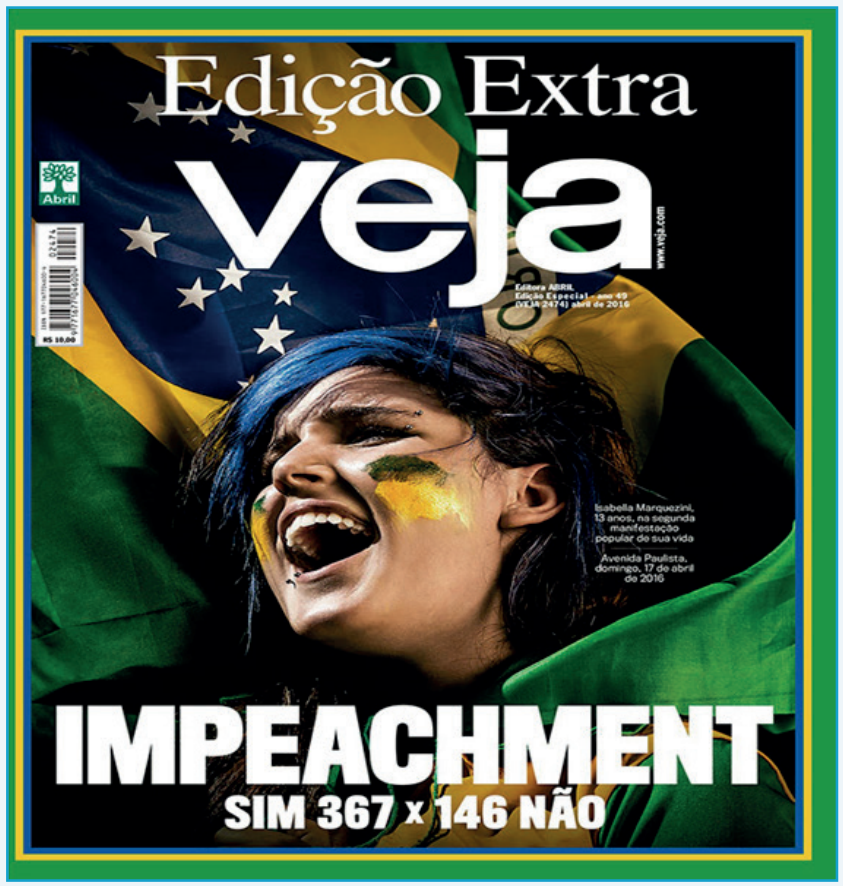

Fonte: Site da Veja

A capa em questão (FIGURA 2) traz uma jovem de 13 anos, Isabella Marquezini, no que seria a comemoração pelo resultado favorável ao impeachment de Dilma. A legenda para a foto explica que essa seria a segunda manifestação popular que a jovem participava. A personagem aparece segurando a bandeira do Brasil, com o rosto pintado de verde e amarelo e uma expressão de extrema felicidade, como se estivesse gritando e comemorando. O fundo está em preto, dando destaque à personagem e as bordas da revista aparecem em verde e amarelo. Os elementos da ca- pa conversam entre si e produzem a sensação de uma grande comemoração a respeito do resultado da aprovação do impeachment.

Depois de antecipar sua edição semanal para abordar os últimos acontecimentos do processo que ainda tramitava, a revista Veja lançou uma versão extra sobre a aprovação do impeachment da presidenta Dilma Rousseff. Na edição anterior, Veja trazia Dilma Rousseff com a manchete 'Fora do Baralho', remetendo à evidente retirada de Dilma da presidência. Percebe-se que a empresa estava apostando alto no retorno das vendas, visto que a publicação de uma revista gera um custo. Além disso, o fato de terem toda uma revista extra com fatos sobre a aprovação e motivos para concordar com ela, faz pensar que já tinham a certeza da aprovação do processo.

$\mathrm{Na}$ edição especial, a manchete 'Impeachment' aparece em letras maiúsculas, em grande destaque ocupando praticamente o mesmo espaço que o nome da revista. Abaixo da palavra 'impeachment', Veja traz 'SIM 367×146 NÃO', que seria o resultado da votação na Câmara dos Deputados, sendo aprovado o prosseguimento do processo de impeachment da presidenta.

A capa remete a algo festivo, uma comemoração. A jovem aparece comemorando o resultado, feliz pelo impeachment. As cores são verde e amarelo na sua maioria, remetendo ao patriotismo. Além disso, a jovem de rosto pintado relembra outro episódio da história brasileira, os protestos dos chamados Caras Pintadas ${ }^{20}$. Este se tratava de um movimento estudantil ocorrido em 1992 que pediu o impeachment do então presidente da República, Fernando Collor de Melo. Na ocasião, diversos jovens saíram às ruas com o rosto pintado de verde e amarelo, mesma situação ocorrida nos protestos contra Dilma.

Embora a cor seja um fenômeno extremamente subjetivo, certas influências no estado psicológico das pessoas são generalizadas. Assim, pode-se classificar alguns significados amplamente relacionados a determinadas cores. Partindo

20 Memória Globo. Disponível em: <http://memoriaglobo.globo. com/programas/jornalismo/coberturas/impeachment-de-collor/oscaras-pintadas.htm>. Acesso em 06 de novembro de 2017 
desse pressuposto, buscou-se desvendar o significado das cores ${ }^{21}$ utilizadas na capa da Veja. Branco é uma cor positiva, símbolo da rendição e da paz. É a cor de luto na China, Índia e no Japão, e originalmente também era na Europa. $\bigcirc$ Verde simboliza a esperança, o dinheiro e é associado à juventude, devido do contraste com o amadurecimento dos frutos. O Amarelo simboliza brilho, vida e esclarecimento e, além de refletir descontração, também pode simbolizar a covardia ou inveja. O Azul, por sua vez, simboliza o aspecto divino e infinito do céu, transmite talento e ingenuidade. Por fim, o Preto simboliza o mau, especialmente pelo fato de representar ausência de cor. Representa o submundo, mas originalmente é associado à autoridade.

A simbologia das cores é fundamental para transmitir diferentes sensações. As revistas conseguem utilizar este dispositivo, visto que usam muitas cores em cada uma de suas edições. $O$ gênero ao qual esses periódicos pertencem, o interpretativo, trata justamente disso: a utilização de diversos recursos para atrair o público.

Melo (2013) explica que o gênero interpretativo exerce um papel esclarecedor e educativo, levando ao leitor mais dados e explicações sobre um mesmo acontecimento. Observa-se que a Veja traz, na capa, apenas duas constatações sobre o impeachment: a juventude comemorando, referindo-se à esperança de melhorias e o resultado em números da votação que aprovou o processo. Beltrão (1976) destaca que o jornalismo interpretativo submete os dados recolhidos a uma espécie de filtro e edição a fim de publicar apenas aquilo que considera significativo para o entendimento do assunto. Sendo assim, ao trazer uma nítida comemoração do resultado, Veja assume que, para a empresa, as informações pró-impeachment são as únicas relevantes e significativas.

Por mais que não seja propriamente dito, a Veja se posiciona a favor do impeachment e traz imagens, fatos, frases que afirmam isso. Um ponto que deve ser ressaltado é que, como indica Young

21 Dicionário dos Símbolos. Disponível em: <https://www. dicionariodesimbolos.com.br/significado-cores/>. Acesso em: 05 de novembro de 2017.
(2000), a imparcialidade não é considerada apenas um ideal inatingível, mas um valor que serve a funções ideológicas precisas. Ela dá suporte à ideia de Estado neutro e legitima a autoridade burocrática e os processos decisórios hierárquicos, que são as manifestações desta neutralidade. Além disso, a imparcialidade reforça a opressão ao transformar o ponto de vista de grupos privilegiados em uma posição universal. Com estes recursos, Veja constrói uma imagem de legitimidade perante os leitores, colocando-se na posição de detentora do saber, frente a um suposto não-saber da população em geral. (BENETTI, 2008).

Conforme Melo (2013), para manter a impressão de imparcialidade e distanciamento, o jornalismo não fala por si, mas por meio de outros que são considerados detentores de uma imagem pública ou de relevância. Percebe-se o uso desta técnica na utilização da personagem principal da capa: a moça de verde e amarelo comemorando. Através dela, a Veja consegue se posicionar de um lado dos acontecimentos e influenciar os leitores a acreditarem apenas nessa percepção da história.

Segundo Scalzo (2006), uma revista semanal de informações não pode levar ao leitor somente um resumo do que ele já viu e reviu durante a semana. A revista precisa explorar novos ângulos, ajustar o foco conforme o público-alvo do veículo. Dessa forma, a Veja traz nesta edição uma capa que não apresenta novas versões do acontecimento ou um outro ângulo que não tenha sido abordado em outras coberturas.

De acordo com Lustosa (1996), a temática desse tipo de jornalismo, o de revista, não é a realidade temporal, mas a conjuntural. Dessa maneira, as revistas podem mostrar um retrato cultural do período em que estão inseridas. Diante disso, a Veja traz o retrato cultural do momento. As comemorações do impeachment, as chamadas festas verde e amarelo, tomaram conta das ruas das capitais do país. Sendo assim, a revista apresenta um recorte da realidade daquele momento.

É notável que as revistas aprofundam a reportagem, dedicando-se a um público em específico e direcionando o seu conteúdo, assumindo, muitas vezes, um posicionamento. $\bigcirc$ jornalismo de revista admite um caráter de entretenimento, informando e divertindo os leitores. Assim, a Veja se 
posiciona através de seu conteúdo tendencioso e traz as informações com ares de descontração e entretenimento. Lage (2011) ressalta que a revista, desde sua capa, precisa encantar o leitor. $O$ autor destaca ainda que as produções precisam envolver o público a tal modo que o faça acreditar naquilo que está lendo, levando como uma realidade fascinante. Ao trazer uma capa festiva, com as cores do Brasil, a Veja encanta o seu leitor, geralmente alinhado à Direita, com toda uma referência às comemorações de patriotismo e de esperança em um futuro melhor para o país.

A partir dos conceitos de Martins (2005), entende-se que o jornalismo político deixou de ser engajado para assumir uma postura isenta. $\bigcirc$ autor explica que anteriormente o leitor comprava o jornal esperando encontrar uma cobertura afinada com seu viés político. Depois dos anos 2000, passaram a assumir uma postura isenta. Ainda segundo Martins (2005), longe de estar desaparecendo, a imprensa de opinião tende a florescer em periódicos, como as revistas, por exemplo. Sendo assim, percebe-se a intenção da revista Veja em ser um porta-voz de determinado grupo político, emitindo opiniões fortes e alinhadas a um lado da história.

\section{A análise}

O surgimento de formas modernas de comunicação midiática e difusão da informação transformaram o estatuto social e político no qual se está inserido. Thompson (2002), ao traçar uma teoria do escândalo político midiático, destaca como o uso contemporâneo da mídia transformou a conduta dos líderes políticos e a vida política em geral. Tendo esta ideia por fio condutor, o objetivo deste estudo é analisar de que forma as revistas Carta Capital e Veja abordaram o impeachment de Dilma Rousseff em suas capas, veiculadas, respectivamente, nos dias 6 de abril e 18 de abril de 2016, considerando os conceitos de escândalo político.

Para tanto, tomou-se como objeto o escândalo midiático que envolveu o impeachment de Dilma Rousseff e as capas das revistas Carta Capital e Veja. Conforme Thompson (2002), o escândalo político midiático é visto como lutas pelo poder simbólico em que a reputação e a confiança estão em jogo. Ele aponta uma série de fatores que constituem o conjunto de forças relativas ao contexto em que essa 'batalha', por gerir as 'cotas' de reputação e confiança, ocorrem. Os elementos caracterizadores do escândalo político midiático, propostos por Thompson (2002), se estendem ao tratamento dado pela mídia a esse fenômeno.

Neste sentido, como foi indicado, usa-se o Poder, a Reputação e a Confiança como categorias para analisar as duas capas selecionadas para este estudo, por meio da técnica de análise de conteúdo (BARDIN, 1979).

\section{Categoria 1: Poder}

Neste momento, pretende-se averiguar como as revistas Carta Capital e Veja utilizaram do poder simbólico, representados nas capas selecionadas, para se colocarem na disputa de uma hegemonia na cobertura jornalística. Thompson (2002) define - poder simbólico como a capacidade de intervir no curso dos acontecimentos, de influenciar as ações e as crenças de outros e de criar acontecimentos, através da produção e transmissão de formas simbólicas. Com isso, o autor revela que aqueles que exercem o poder simbólico utilizam diversos recursos que ele denomina como 'meios de informação e comunicação'. Ele observa, ainda, que o exercício do poder simbólico é uma das principais formas de aquisição do poder político.

Thompson (2002) ressalta que o uso do poder simbólico não é acidental ou secundário à luta pelo poder político, mas é essencial a ele. Todo aquele que quiser conquistar poder político ou exercê-lo de uma maneira durável e efetiva, deve também usar o poder simbólico para cultivar e sustentar a crença na legitimidade. Assim como a Carta Capital, a Veja faz parte de um jogo político por poder.

É bastante evidente que a revista Carta Capital deu destaque à questão do golpe, ao ato ilegal do impeachment e suas consequências para a democracia brasileira. O termo 'golpe', no sentido de comparar aos acontecimentos do passado, dá o tom do ponto de vista reprovador calcado 
na questão democrática. Portanto, a revista busca que os leitores utilizem do mesmo discurso como contraponto à oposição política de Dilma Rousseff. Há com isso, o incentivo para que o público se manifeste contrário ao processo, na tentativa de que provem, com a negativa do impeachment, estarem certos em suas afirmativas de golpe.

Por outro lado, a revista Veja destaca o verde e o amarelo, cores da bandeira do país, traz à tona um suposto patriotismo e uma comemoração pelos episódios de protesto. A palavra 'impeachment' em destaque com apoio do resultado da votação demonstra o tom de aprovação da empresa ao processo. O motivo, segundo a Veja, é a esperança de um Brasil melhor. A revista busca que os leitores se orgulhem do movimento pró-impeachment, que comemorem o resultado com a 'festa verde e amarela'.

A sociedade moderna nasceu baseada na informação. No mundo de hoje, o 'jogo do poder' se dá na mídia. O público, por sua vez, ao acreditar na isenção da mídia, pode acabar elegendo ou afastando determinado político ou partido. Com o passar dos anos, apesar do Jornalismo ter assumido um papel mais imparcial, conforme trazido por Martins (2005), ainda nos dias de hoje, posiciona-se deste ou de outro lado para apoiar alguma personalidade política e também ir ao encontro dos interesses comerciais da própria empresa. Assim, conforme Melo (2013), a imprensa ainda, utiliza-se por ser um porta-voz para emitir opiniões e persuadir o público a adotar a mesma postura.

De diferentes maneiras, acredita-se as organizações de mídia estão todas interessadas no exercício do poder simbólico através do uso dos meios de comunicação de vários tipos. Conforme Thompson (2002), algumas dessas organizações estão ligadas diretamente ao campo político, mas não se identificam com ele, pois são geralmente governadas por princípios diferentes e orientadas para diferentes finalidades. Está exposto neste jogo que o objetivo é de impactar e surpreender o receptor, seja ele leitor, ouvinte ou espectador. A disputa tem deslocado a verdade como parte que fundamenta a informação, submetendo o destinatário a um constante exercício logístico de bom senso e de equilíbrio para identificar o que é excesso e o que é irreal daquilo que é fato verídico 22 .

Vale ressaltar a opção da editoria da Veja em mudar as cores originais do nome da publicação que vem estampado na capa. Fugindo do habitual vermelho e trazendo no lugar o branco, a Veja ressalta a tentativa de provocar sentimentos de esperança e paz, trazidos supostamente pelo resultado favorável ao impeachment. Além disso, se coloca como parte da bandeira do Brasil, se tornando um dos estados que compõe a bandeira em forma de estrela. Pode ser lida como tentativa de se colocar como parte da população e que comemora, como o povo, o resultado positivo. Destaca-se que o vermelho, presente normalmente na escrita do nome da Veja, também é a cor do partido ao qual Dilma pertence e, talvez, o veículo tenha buscado se manter distante dessa ideia o substituindo pelo branco.

A Carta Capital traz ao leitor uma capa que remete ao luto e ao sentimento de que o país teria sofrido um golpe. As manchetes e a linha de apoio em tom de afirmação reforçam essa ideia. $\bigcirc$ preto e branco da foto da capa podem ser entendido como luto, como a chegada de dias sem sol, nublados e obscuros. Remeter ao golpe de 1964 é trazer à tona o obscurantismo vivido durante os anos de chumbo, quando a brasilidade perdeu o tom. As manchetes remetem a outros países que vivem o totalitarismo e a falta de liberdade.

\section{Categoria 2: Reputação}

Conforme Thompson (2002), muitas vezes não só a figura central de um escândalo político tem a reputação prejudicada e/ou a carreira (ou mesmo vida pessoal) arruinada. Os danos podem se estender a outras pessoas implicadas em menor grau ou mesmo instituições e organizações políticas com as quais essas pessoas estiveram ligadas. Nesse sentido, é pertinente um olhar acurado sobre como a mídia retrata o que se pode chamar de dissociação das 'más companhias', ou seja, as referências feitas a um partido que tentar banir um

22 Disponível em: <http://conexao.cpb.com.br/secoes/capa/adisputa-pelo-poder>. Acesso em: 06 de novembro de 2017. 
membro que esteja com a imagem comprometida. Prevendo o desgaste na reputação, o governo e as próprias revistas tentam traçar o provável desenvolvimento futuro do escândalo e o impacto que terá no campo político do país.

Não é regra que escândalos destruam a reputação e enfraqueçam a confiança, mas eles têm o potencial considerável de fazer isso. E é devido a essa capacidade, esse potencial de prejudicar a reputação e corroer as relações de confiança, que os escândalos têm tanta importância no campo político.

Nesse sentido, a Carta Capital aparece com uma tentativa de pôr em dúvida a credibilidade dos adversários de Dilma Rousseff, como o próprio $\mathrm{FHC}$ quando traz uma manchete remetendo a possíveis negócios ilegais ou grandiosos que teriam descoberto. Mas, verifica-se que o foco central da publicação é salvar a reputação de Dilma, a colocando como uma vítima do jogo político, embora seu nome e nem de seu partido sejam citados. Anterior ao impeachment propriamente dito, Carta Capital mostrou preocupação em apontar as estratégias do governo para driblar a crise que se principiava ${ }^{23}$. A revista também aponta que diferentes políticos se posicionaram a favor do impeachment como forma de se aproveitar da situação ${ }^{24}$.

Para Thompson (2002), a reputação tem quatro características principais: é preciso um longo período de tempo para consegui-la; é contestável; o uso não a esgota; e é dificilmente restaurada. A partir da avaliação de como os escândalos midiáticos atingem as características básicas da reputação, o autor elenca uma série de consequências negativas desses escândalos. Uma delas é o risco de geração de um clima de desconfiança. Outra é o fato do escândalo midiático produzir um ambiente que valoriza mais a reputação de caráter que a reputação de competência. Segundo o autor, isso pode produzir um ambiente de niilismo

23 Carta Capital. Disponível em: <https://www.cartacapital.com.br/ revista/885/a-vez-da-coragem $>$. Acesso em: 07 de novembro de 2017.

24 Carta Capital. Disponível em: <https://www.cartacapital.com.br/ revista/891>. Acesso em: 07 de novembro de 2017. e ceticismo capaz de levar setores da população a abandonarem totalmente o processo político.

Dessa forma, a Veja aparece com a tentativa de manchar a reputação de Dilma e do Partido dos Trabalhadores (PT), ao qual ela pertence. Uma vez com a reputação abalada, como propõe Thompson (2002), dificilmente é restaurada. Por mais que Dilma provasse estar certa, que o impeachment não passasse no Senado, a confiança na figura da presidente estaria abalada. Nesse sentido, conforme Dines (1986), o sensacionalismo é comumente associado a situações que incluem apelos gráficos, linguísticos, temáticos, deslizes informativos, mentiras e exageros. Entretanto, esses fatores atendem às necessidades psicanalíticas do receptor e contribuem para os efeitos no destinatário sejam intensos. Ainda segundo os estudos de Dines (1986), o visual e as cores e as palavras de efeito são características do sensacionalismo.

As capas das revistas Veja e Carta Capital estão aí para mostrar o que é sensacionalismo25. A Carta mostra o episódio de aprovação do impeachment como algo terrível ao país, remetendo a momentos da história com que isso se pareceria. Além disso, ao trazer referências a um período de luto, remete à morte de algo, o que seria um dano irreparável. A comemoração trazida pela Veja transformou o episódio num grande espetáculo midiático. Trouxe o patriotismo como forma de dar a entender que qualquer cidadão que ame seu país também devesse comemorar. As duas, então, utilizam de elementos do sensacionalismo para provocar o público a pensar de determinada forma e a assumir a mesma linha de linguagem.

A construção da imagem positiva de seus aliados e a desconstrução e desqualificação do opo-

\footnotetext{
25 Nome dado a um tipo de postura editorial adotada regular ou esporadicamente por determinados meios de comunicação, que se caracteriza pelo uso exagerado de determinadas expreções não exatamente usadas por quem ocorreram os fatos, o senacionalismo além de caracterizado pelo apelo emotivo e pelo uso de imagens chocantes na cobertura de um fato também se caracteriza pela capacidade de induzir o telespectador prender-se a fatos em sua maioria destorcidos trazendo para si uma realidade irreal e alterada do cotidiano do dia a dia. Exagero de tal fato exibido com muitas cenas emotivas e de certa forma generalizando o tema exibido. Ultimamente, usa-se esse recurso para ganhar audiência, pois choca a mente dos espectadores. Disponível em: <http://www. dicionarioinformal.com.br/sensacionalismo/>. Acesso em: $17 \mathrm{de}$ novembro de 2017
} 
sitor, segundo Magalhães (2015), é um jogo diário que perpassa décadas. Diversos políticos adquirem ou comandam revistas, emissora de TV ou rádio e jornais. O motivo do interesse nos veículos de comunicação pode estar na possibilidade que geram de construir ou destruir reputações, como verificado nas duas revistas analisadas.

\section{Categoria 3: Confiança}

Cada vez mais, os partidos e seus líderes têm de lutar para ganhar o apoio de uma crescente parcela de eleitores não comprometidos, isto é, de eleitores cujas afiliações políticas têm menos probabilidade de passarem de uma geração a outra e que mais provavelmente irão tomar suas decisões baseados nas opções a eles oferecidas (THOMPSON, 2002). As características da confiança, segundo Thompson (2002), são: seu uso não só não a esgota como a reforça; é vulnerável; e pode ser suplementada por vários mecanismos, como contratos, cartas de acordo e procedimentos.

Conforme Magalhães (2015), com o enfraquecimento da política baseada em partidos classistas que representavam interesses de distintas classes sociais, cresce a política de confiança. Nesse contexto de disputa, entende-se que grupos de interesse estão continuamente empenhados em atacar os 'concorrentes'. Qualquer infortúnio que venha prejudicar o desempenho do adversário será celebrado pelo opositor. Por isso, é importante estar atendo às referências feitas às reações dos adversários políticos, ou seja, como a mídia retrata o comportamento de líderes de partidos opositores, por exemplo, inclusive às vezes assumindo declaradamente estratégias para se beneficiar do infortúnio que atinge o concorrente.

$\mathrm{Na}$ capa proposta pela Carta Capital, a revista também utiliza desse elemento, trazendo um enunciado de uma matéria sobre Fernando Henrique Cardoso, do partido PSDB, oposição ao PT, sobre os negócios no Brasil e no exterior. A manchete e a foto utilizados dão a entender que o tema é desfavorável ao ex-presidente. Além disso, seguindo as observações de Dondis (2000), a Carta Capital traz elementos que induzem o leitor a apostarem na presidente deposta e a lutarem pa- ra que seu governo seja reestabelecido, para o bem da democracia brasileira e para evitar que dias obscuros como os que o Brasil viveu com o golpe de 1964 voltem a assolar a nação.

Dessa maneira, segundo Melo (2013), a narrativa jornalística tende a representar a política enquanto jogo ou competição, estimulando ou até mesmo criando situações de rivalidade. Essa representação é frequentemente usada pelo jornalismo na cobertura de campanhas políticas como forma de estimular o interesse do público e torná-las mais atraentes. Os meios de comunicação de massa intensificaram o processo de dramatização da vida política, tornando-a mais próxima do cotidiano.

A Veja, por sua vez, apostou em estimular a confiança dos leitores a respeito de um futuro meIhor para o país. A ideia passada pela publicação consiste em destacar o positivismo que vem com a aprovação do impeachment, como se fosse algo que o país estivesse precisando para melhorar. O conceito festivo da capa induz o leitor a pensar que momentos melhores virão e que podem, novamente, confiar no poder político.

Para Lage (2011), um dos grandes riscos do jornalismo interpretativo é subordinar a matéria a crenças ou teorias não comprovadas, transformando a informação em opinião, diante da qual o receptor poderá apenas concordar ou discordar. Sendo assim, entende-se que tanto Veja quanto Carta Capital colocam suas opiniões à frente da informação propriamente dita, já que se posicionam de um lado ou de outro. $O$ mesmo autor destaca que essa tendenciosidade do jornalismo de revista e também, do gênero interpretativo, é o que a torna mais atraente ao leitor. $\bigcirc$ receptor busca veículos e produtos noticiosos que mais se aproximem do seu ponto de vista.

Conforme visto por Scalzo (2004), a revista, mais do que um meio de comunicação, é um negócio, uma marca. Dessa forma, mais do que oferecer a informação e proporcionar conteúdo para que o leitor tome suas conclusões, a revista busca vender uma ideia, ser associada a algo e a atingir seu público-alvo. Essas características fazem com que o público-alvo, tanto da Veja quanto da Carta Capital, espere certo posicionamento do veículo e confie nas informações por elas prestadas, sem 
deixar rastros de dúvidas.

Como explica Barreto (2006), a narrativa jornalística constrói uma forma de percepção em torno da política. Mais do que apresentar relatos, o jornalismo faz um recorte da realidade a ser apresentada. Sendo assim, o leitor acredita estar recebendo as informações mais relevantes sobre determinado assunto, confiando no emissor.

\section{As capas e o escândalo político}

A pergunta em que essa análise se baseou foi: de que forma as revistas Carta Capital e Veja abordaram o impeachment de Dilma Rousseff em suas capas, veiculadas, respectivamente, nos dias 6 de abril e 18 de abril de 2016, considerando os conceitos de escândalo político? Verificou-se que a Carta Capital trouxe uma capa totalmente contrária ao impeachment, enquanto a Veja trouxe a comemoração pelo resultado.

Toda a análise foi realizada com embasamento teórico sobre jornalismo de revista, jornalismo político, capas de revista, escândalo político e gênero interpretativo. Dessa forma, observou-se a utilização de técnicas descritas no referencial do presente trabalho, a fim de mobilizar o leitor e o induzir a um pensamento único. Identifica-se ambas as capas como tendenciosas e que utilizam de linguagem persuasiva.

A partir da análise dos elementos contidos nas capas da Veja e da Carta Capital, verificou-se a posição política/ideológica de cada um dos veículos e a relação destes com a sociedade. Cada publicação apresentou a sua visão de um mesmo acontecimento, com base em suas crenças e valores, como visto nos estudos de Lage (2011). Partindo da leitura das pesquisas feitas na área de jornalismo de revista, observou-se que tanto Veja quanto Carta Capital utilizam das técnicas e apresentam as características descritas pelos autores deste estudo. $O$ jornalismo de revista precisa envolver o público e gerar impacto através do conteúdo exposto, além disso é geralmente carregado de opinião, utiliza maior quantidade de recursos para passar uma ideia, como textos, imagens, cores e infográficos, além de aprofundar e refinar o relato. Destaca-se também, que precisa estar de acordo com a opinião do público consumidor.

É perceptível a diferença entre as duas abordagens. Enquanto a Carta Capital apresentou uma capa se colocando contra o impeachment e por consequência, contra o 'golpe' e ao lado de Dilma, Veja se posicionou a favor do impeachment e daqueles que o julgavam necessário, chegando a comemorar o resultado. Os veículos de comunicação exercem grande influência na sociedade e na opinião do público, que posteriormente os utiliza como base em debates e como pautas no ambiente político. Como exemplificado, a confiança está diretamente ligada ao relacionamento entre mídia e público, que utilizam do poder como uma da outra para propagar suas ideologias.

O fato da Carta Capital ter relacionado o processo de impeachment com a ditadura militar de 1964, ressalta a ideia de golpe, propagada pela empresa para incentivar o público a adotar a mesma linha de pensamento. Além disso, as cores da capa remetem às cores do partido de Dilma, o PT, que indica mais ligação favorável à presidente. Além, claro do breu característico do uso de uma fotografia preto e branco para mencionar os dias difíceis que estariam por vir, a partir do resultado da votação.

A Veja trouxe o mesmo discurso utilizado pela Direita no geral: a festa verde e amarelo, a juventude comemorando o impeachment. A capa remete à comemoração e à esperança de dias melhores. Também pode ser lida como algo mais patriota, por trazer em grande parte as cores nacionais e a bandeira do Brasil. Além disso, remete a outro importante movimento que derrubou o presidente da época, Fernando Collor, os cara-pintada.

Pelas referências de jornalismo de revista, capa de revista, escândalo político e jornalismo político e com a construção da linha editorial de Carta Capital e Veja, nota-se que mesmo tratando de um único assunto, as editorias têm seus ideais e concepções que formam o conteúdo que querem apresentar. A formação de cada editoria faz a construção de cada revista e, assim, da capa. De acordo com o que foi apresentado, a capa é o cartaz da revista. Ela representa o que a revista pretende abordar a partir de determinado acontecimento. Essa abordagem leva um ponto de vis- 
ta único e que representa o grupo editorial. Por esses motivos, não é possível encontrar um único imaginário a partir das duas capas, mas sim, um imaginário para cada capa. Sendo que, a Carta afirmou que o impeachment é golpe e que o país sofreria as consequências, e a Veja mostrou o impeachment como a possível salvação da nação.

Como visto, escândalo político envolve revelação, publicação, defesa, dramatização, execução e rotulação. Uma das consequências de tal acontecimento é o prejuízo que gera à imagem e reputação dos envolvidos. No momento da publicação das edições estudadas, o impeachment já configurava um escândalo político e já estava na mídia há algum tempo. As edições abordam o resultado de todo esse processo, trazendo suas próprias visões daquele acontecimento e o que ele geraria futuramente.

A Carta Capital, ao trazer ligação da capa ao Golpe de 1964, demonstra estar ao lado da personagem principal desta história: Dilma. Além disso, demonstra interesse em manchar a reputação da oposição ao utilizar uma imagem e manchete difamatórias a respeito de FHC e indicar outros países que vivem sob repressão. A Veja, ao contrário, traz elementos e uma personagem jovem e feliz para reforçar a ideia de festa e comemoração, como algo que remete também, à esperança e um futuro positivo.

\section{Conclusão e sugestões}

O presente trabalho tem como tema o jornalismo de revista e os conceitos de escândalo político, tendo como delimitação o episódio de impeachment da presidente Dilma Rousseff, em uma análise de capas das revistas Carta Capital e Veja, veiculadas nos dias 6 e 18 de abril de 2016. A imprensa é o principal meio facilitador da comunicação entre a população e seus representantes políticos, uma vez que, no cotidiano, o povo é apartado das rotinas e das decisões que competem ao Estado. Portanto, a imprensa tem como função, em sua qualidade de 'Quarto Poder', acompanhar os governantes e as instituições e observar de perto os bastidores da política, prezando sempre pela informação precisa e pelo debate de interesse público.

Entende-se que a imprensa é composta por pessoas e organizações que são dotadas de subjetividade. Dessa forma, as reportagens recebem forte influência das questões implícitas a esses atores que produzem o conteúdo. $\bigcirc$ que se percebe é que diversos veículos apresentam recortes da realidade e não o acontecido em sua totalidade. Isso não permite que o receptor dessa informação possa tomar suas próprias conclusões a respeito, uma vez que a empresa oferece apenas um lado do ocorrido.

Foi a partir desse entendimento que se decidiu investigar os olhares produzidos pelas revistas Carta Capital e Veja a respeito do processo de impeachment de Dilma Rousseff. Para a realização do estudo foram selecionadas capas de edições impressas de Carta Capital e Veja publicadas no período da primeira votação, na Câmara dos Deputados. Carta Capital é assumidamente esquerdista. A Veja, não assumidamente, mostra-se, no entendimento da pesquisadora, alinhada às pautas direitistas.

Acusada por pedaladas fiscais, Dilma sofreu impeachment após vários meses de debate, protestos e desavenças políticas. Inclusive o seu vice, Michel Temer foi um de seus adversários no processo. Temer, hoje presidente da República, divulgou documentos se mostrando insatisfeito e contrário ao posicionamento de Dilma. Além disso, demonstrou grande interesse na aprovação do impeachment. Todo esse episódio pode ser entendido como escândalo político.

A partir de três categorias de análise - Poder, Reputação e Confiança, a pergunta que baliza este estudo foi: de que forma as revistas Carta Capital e Veja abordaram o impeachment de Dilma Rousseff em suas capas, veiculadas, respectivamente, nos dias 6 de abril e 18 de abril de 2016, considerando os conceitos de escândalo político, foi respondida. Na capa da Veja, predominou o entendimento de que o impeachment é um processo legítimo, previsto pela Constituição e com a justa condução assegurada pelas instituições parlamentares e pelo Supremo Tribunal Federal. Veja procurou provar que a petista e seus partidários, como o ex-presidente Lula, não foram vítimas inocentes de uma conspiração da oposição, 
enfatizando as manifestações pró-impeachment e o tom festivo da decisão favorável ao processo.

Por outro lado, Carta Capital enfatizou a abordagem do impeachment como um golpe. Ainda nesta perspectiva, a publicação trabalhou de maneira a remeter e reviver os episódios de Golpe de Estado vividos por Brasil, Honduras e Paraguai, relacionando um acontecimento ao outro. $O$ tom da capa dá entender que futuramente, assim como ocorrido naquela época, um dia, o processo de impeachment de Dilma será estudado como um golpe político. A revista enfatizou os interesses que estariam por trás do desejo de impeachment de Dilma Rousseff e os principais atores que teriam orquestrado a 'conspiração': Eduardo Cunha, movido pelo desejo de vingança; Michel Temer e parte do PMDB, movidos pela aspiração de tomar o poder; e setores do mercado, que estariam insatisfeitos com a condução da economia.

Perante questões tão complexas como as que permearam o processo de impeachment, não houve imparcialidade na divulgação do evento ao público, considerando as capas estudadas. O conteúdo de ambas as revistas parece ter se baseado, essencialmente, em análises e opiniões dos próprios veículos, o que contempla a hipótese deste estudo de que as duas revistas teriam sido parciais, Carta alinhada à esquerda e Veja à direita. A Carta Capital trouxe uma visão contra o impeachment, tentando mostrar que se tratava de jogo político. A revista Veja apareceu com discurso favorável ao impeachment, transformando o processo numa grande festa da democracia.

A comunicação é onipresente nas organizações e na vida humana. Dessa forma, entendê-la na sua amplitude multifacetada é quase impossível. Nesta pesquisa, não houve a pretensão de esgotar a discussão a respeito do tema, mas de contribuir com a análise da comunicação na área política. As análises foram realizadas com o auxílio de material teórico, mas também com a per- cepção de elementos básicos presentes nas referidas capas.

Esta pesquisa é apenas um passo na busca pela compreensão de como as capas de revista se relacionam com a sociedade e sua importância dentro do contexto de escândalo político. Contudo, acredita-se na ampliação da discussão e reflexões acerca dos temas apresentados, juntamente à apreciação dos veículos noticiosos Carta Capital e Veja. São temas relevantes ao campo da Comunicação. Não se pretende então, esgotar o assunto nesta pesquisa, mas sim contribuir para novos conhecimentos e gerar possibilidades para novas pesquisas. Assim, os objetivos foram traçados e tão logo alcançados, com a análise da relação entre os aspectos identificados nas duas capas. Após a descrição das capas, houve a pronta identificação dos aspectos e suas respectivas análises, visando o arremate da pesquisa.

Este estudo permitiu um novo olhar sobre a teoria social dos escândalos políticos midiáticos, desenvolvida por John B. Thompson, com relação ao tratamento dado por duas revistas a respeito do impeachment de Dilma Rousseff. Infere-se que a mídia se prevalece da imagem de personagens políticos de relevância para alcançar o poder simbólico, tão bem descrito por Thompson, e o monopólio das informações. Acredita-se que os veículos de comunicação devem ser aliados da sociedade para exigir o cumprimento de compromisso ético e cobrar dos representantes políticos um comportamento confiável. Ao contrário disso, observou-se que as mídias utilizam de privilégios por serem porta-voz para disseminar apenas um lado da história, coagindo e incentivando os leitores a seguirem o mesmo ponto de vista.

Neste sentido, sugere-se como um estudo futuro, uma pesquisa baseada na recepção. Seria interessante saber dos leitores o que eles entendem e percebem das capas, das publicações e das temáticas apresentadas por esta pesquisa. 


\section{Referências}

ALBUQUERQUE, Afonso de. Aconteceu num Carnaval: algumas observações sobre o mito de origem do jornalismo brasileiro moderno. Porto Alegre: Insular, 2008.

ALECRIN, Rosimeire. A linguagem semiótica presente em capas de revista Veja. Disponível em: <http://www. unigran.br/interletras/ed_anteriores/n18/artigos/2.docx>. Acesso em: 17 de outubro de 2017.

ALMEIDA, Vitor Pereira; RODRIGUES, Cecília; FELZ, Jorge Carlos. Análise do conteúdo jornalístico da revista Carta Capital. Disponível em <http://portalintercom.org.br/anais/nacional2015/resumos/R10-1940-1.pdf>. Acesso em 27 de abril de 2017.

AMARAL, L. A objetividade jornalística. Porto Alegre: Ed. Sagra-D.C. Luzzatto, 1996.

ANDRÉ, M. E. D. A. Texto, contexto e significados: algumas questões na análise de dados qualitativos. Cadernos de Pesquisa, São Paulo, n. 45, p. 66-71, maio 1983.

AZEVEDO, Fernando. Corrupção, mídia e escândalos midiáticos no Brasil. Belo Horizonte: Em Debate, 2010.

BALBINOTTI, M. A. A.; SALDANHA, R. P.; BALBINOTTI, C. A. A.. Dimensões motivacionais de basquetebolistas infanto-juvenis: um estudo segundo o sexo. Revista Motriz, Rio Claro, v.15, n.2, p.318-329, abr./jun. 2009. Disponível em: <http://www.periodicos.rc.biblioteca.unesp.br/index.php/motriz/article/view/2513/2356>. Acesso em: 15 de setembro de 2017.

BARDIN, Laurence. Análise de conteúdo. Lisboa: Edições 70, 1977.

BELTRÃO, L. Jornalismo Interpretativo: filosofia e técnica. Porto Alegre: Sulina, 1976.

BENETTI, Márcia. A ironia como estratégia discursiva da revista Veja. Libero, 2008. Disponível em: <htlp:// revistas.univerciencia.org/index.php/libero/article/download/4644/4368 > Acesso em: 17 de agosto de 2017.

BEZERRA, M.O. Corrupção: um estudo sobre poder público e relações pessoais no Brasil. Rio de Janeiro: Relume-Dumará e Anpocs, 1995.

BOBBIO, Norberto. Esquerda e Direita: razões e significados de uma distinção política. 1994. Disponível em: <http://dagobah.com.br/wp-content/uploads/2017/01/BOBBIO-Norberto-1994-Direita-e-esquerdaRaz\%C3\%B5es-e-significados-de-uma-distin\%C3\%A7\%C3\%A3o-pol\%C3\%Adtica.pdf>. Acesso em: 05 de novembro de 2017.

BONELLI, Marco Antônio Gusmão. O retrato da política: cobertura jornalística e eleições. In: GOLDMAN, Márcio; PALMEIRA, Moacir. (Orgs). Antropologia, voto e representação política. Rio de Janeiro: Contracapa, 1996. p. 84 a 102.

BRASIL. Conheça a trajetória da presidenta Dilma Rousseff. Disponível em: <http://www.brasil.gov.br/ governo/2015/01/conheca-a-trajetoria-da-presidenta-dilma-rousseff> Acesso em: 28 de junho de 2017

BUITONI, Dulcília Schroeder. Imprensa feminina. São Paulo: Ática, 1986.

CAMPOS, Pedro Celso. Gêneros do jornalismo e técnicas de entrevista. 2009. Disponível em: <http://www. periodicos.ufsc.br/index.php/jornalismo/article/viewFile/10952/10422> Acesso em: 20 de setembro de 2017.

CARTA CAPITAL. Disponível em: <http://www.cartacapital.com.br/editora/cartacapital>. Acesso em: 27 de abril de 2017. 
Tempos de Chantagem. Disponível em: <https://www.cartacapital.com.br/revista/879/tempos-dechantagem-8801.html>. Acesso em: 14 de outubro de 2017.

CENTRO DE PESQUISA E DOCUMENTAÇÃO DE HISTÓRIA CONTEMPORÂNEA DO BRASIL. Disponível em: <http://cpdoc.fgv.br/producao/dossies/Fatoslmagens/Golpe1964>. Acesso em: 21 de outubro de 2017

CHAIA, Vera. Jornalismo e política. São Paulo: Hacker, 2001.

DIAS, Paulo da Rocha et. al. Gêneros e formatos na Comunicação massiva periodística: um estudo do jornal Folha de S. Paulo e da revista Veja. In: Congresso Brasileiro de Ciências da Comunicação. São Paulo: Intercom, 1998.

DINES, Alberto. O papel do jornal: uma releitura. 4. ed. São Paulo: Summus, 1986.

DONDIS, Donis A. Sintaxe da linguagem visual. São Paulo: Ed. Martins Pontes, 1997.

EL PAÍS. Ditadura Militar: quem pede a volta sabe o que é?. Disponível em: <https://brasil.elpais.com/ brasil/2015/04/01/opinion/1427860120_903017.html> Acesso em: 21 de outubro de 2017.

FERNANDES, Florestan. O PT em movimento. São Paulo: Cortez, 1991.

FOLHA DE SÃO PAULO. Em carta desabafo a Dilma, Temer diz que foi desprezado. Disponível em: <http:// www1.folha.uol.com.br/poder/2015/12/1716259-em-carta-desabafo-a-dilma-temer-diz-que-foi-desprezado. shtml>. Acesso em: 28 de setembro de 2017.

FONSECA, João José Saraiva da. Metodologia da pesquisa científica. Ceará: Universidade Estadual do Ceará, 2002.

GIL, Antonio Carlos. Métodos e técnicas de pesquisa social. São Paulo: Atlas, 2008.

GOMES, Pedro Gilberto. Comunicação Social: filosofia, ética e política. São Paulo: Unisinos, 1997.

GOULART, Alexander. Uma lupa sobre o jornalismo de revista. Observatório da Imprensa, 2006. Disponível em <http://www.observatoriodaimprensa.com.br/artigos.asp?cod=388DAC001>Acesso em 21 de setembro de 2017.

JEWITT, C; OYAMA, R. Visual Meaning: a social semiotic approach. In: VAN LEEUWN, T; JEWITT, C. Handbook of visual analysis. London, Thousand Oaks. New delhi: Sage Publications, 2001.

JUNQUEIRA, Vevila. O mensalão inserido na teoria dos escândalos políticos. Disponível em: <http://www2.faac. unesp.br/publicacoes/anais-comunicacao/textos/22.pdf>Acesso em: 25 de setembro de 2017.

KUCINSKI, Bernardo. A síndrome da antena parabólica ética no jornalismo brasileiro. São Paulo: Fundação Perseu Abramo, 1999.

LAGE, Nilson. Ideologia e técnica da notícia. Florianópolis: Insular, 2001.

LASSWELL, Harold. A estrutura e a função da comunicação na sociedade. (Tradução de Gabriel Cohn). In: COHN, Gabriel (Org.). Comunicação e indústria cultural. 5. ed., São Paulo: T.A Queiroz, 1987.

LESLIE, Jeremy. Novo design de revistas. Barcelona: S.L, 2003.

LIMA, Eduardo Pereira. Páginas ampliadas: o livro-reportagem como extensão do jornalismo e da literatura. 4. ed. São Paulo: Manole, 2009.

LUSTOSA, Elcias. O texto da notícia. Brasília: UnB, 1996. 
MAGALHÃES, Eleonora. Jornalismo Político no Brasil: polarização estéril ou arena de debates? Disponível em: $<$ http://www.teoriaepesquisa.ufscar.br/index.php/tp/article/viewFile/450/302> Acesso em: 18 de setembro de 2017.

MARTINS, Franklin. Jornalismo Político. São Paulo: Editora Contexto, 2005.

MEDINA, Cremilda de Araújo; LEANDRO, Paulo Roberto. A arte de tecer o presente: jornalismo interpretativo. São Paulo: Edição dos Autores, 1973.

Notícia: um produto à venda. 6. ed. São Paulo: Summus, 1998.

MELO, José de Marques. Jornalismo opinativo: gêneros opinativos no jornalismo brasileiro. 3. ed., Campos do Jordão: Mantiqueira, 2003.

MIGUEL, Luis Felipe. Os meios de comunicação e as práticas políticas. São Paulo: Lua Nova, 2002.

MILLER, C.R. Estudos sobre gênero textual, agência e tecnologia. Ângela Paiva, Judith Chambliss Hoffnagel (Orgs.); Tradução e adaptação de Judith Chambliss Hoffnagel et. al. - Recife: Ed. Universitária da UFPE, 2009.

MIRA, Maria Celeste. O leitor e a banca de revista. Editora Olho D'agua, 2001.

MOREIRA, D. A. Pesquisa em Administração: Origens, usos e variantes do método fenomenológico. Revista de Administração e Inovação, v. 1, n. 1, 2004.

NAVA, Rosa Maria Ferreira Dales. Saber para continuar: a história do Departamento de Pesquisa e Documentação do Jornal do Brasil e a implantação pioneira do jornalismo interpretativo no país. Dissertação (Mestrado em Comunicação Social) - Universidade Metodista de São Paulo, São Bernardo do Campo, 1996. 132 p.

NIXON, Raymond. Análise sobre periodismo. Quito: Ciespal, 1963.

PICHELLI, Kátia R.; PEDRO, Margarete; CARVALHO, Marcelle de A. (2006). O discurso de formação da opinião pública: análise dos editoriais sobre as denúncias do "Mensalão" nas revistas Veja e Carta Capital. Disponível em: <http://www.unirevista.unisinos.br/_pdf/UNIrev_Pichelli.PDF> Acesso em 15 de junho de 2017.

PINTO, Eduardo Costa. DILMA: de "coração valente" à "presidenta acuada". 2015 Disponível em: <http://www. ie.ufr.br/intranet/ie/userintranet/hpp/arquivos/170820154652_ArtigodeOpinioDilma....16.08.2015.pdf>. Acesso em: 26 de setembro de 2017.

PORTAL PLANALTO. Trajetória da presidenta Dilma Rousseff. Disponível em: <http://www.brasil.gov.br/ governo/2015/01/conheca-a-trajetoria-da-presidenta-dilma-rousseff>. Acesso em: 11 de junho 2017.

POÇAS, Maria Teresa. Design Editorial: Revistas, Capas e Discursos. Disponível em: <http://repositorio.ufpe.br/ bitstream/handle/123456789/3244/arquivo2203_1.pdf?sequence=1\&isAllowed=y> Acesso em: 14 de setembro de 2017.

SANTAELLA, Lúcia e NÖTH, Winfried. Imagem, cognição, semiótica, mídia. 2. ed. São Paulo: Iluminuras, 2001.

SCALZO, Marília. Jornalismo de revista. São Paulo: Contexto. 2006.

SEABRA; SOUSA. (Org.). Jornalismo político - teoria, história e técnicas. Rio, Record, 2006.

SECRETARIA DE COMUNICAÇÃO SOCIAL DA PRESIDÊNCIA DA REPÚBLICA. Pesquisa brasileira de mídia. Disponível em: <http://www.secom.gov.br/atuacao/pesquisa/lista-de-pesquisas-quantitativas-e-qualitativas-decontratos-atuais/pesquisa-brasileira-de-midia-pbm-2015.pdf>. Acesso em: 18 de novembro de 2017. 
SEVERINO, Attönio Joaquin. Metodologia do Trabalho Científico. São Paulo: Cortez, 2007.

SITE G1. Processo de Impeachment de Dilma. Disponível em: <http://g1.globo.com/politica/processo-deimpeachment-de-dilma/ >. Acesso em: 18 de junho de 2017.

THOMPSON, J.B. Ideologia e cultura moderna teoria social crítica na era dos meios de comunicação de massa. Petrópolis, Editora Vozes, 1995.

TRINDADE, Eneus. Semiótica na comunicação publicitária: alguns pingos nos "is" Revista Com ciência.

http://www.comciencia.br/comciencia/?section=8\&edicao=11\&id=77 >. Acesso em:16 de setembro de 2017.

VILAS BOAS, Sérgio. O estilo magazine: o texto em revista. 1. ed. São Paulo: Summus, 1996.

VILLALTA, Daniella. O surgimento da revista Veja no contexto da modernização brasileira. Disponível em: <http://www.renatodelmanto.com.br/casper/Surgimento-de-Veja.pdf> Acesso em: 27 abr 2017.

VEJA. Disponível em <http://www.grupoabril.com.br/pt/quem-somos/historia/>. Acesso em 27 de abril de 2017

VERGARA, S. C. Projetos e relatórios de pesquisa em administração. 8. ed. São Paulo: Atlas, 2007.

WEBER, Max. El político y el científico. Madrid: Alianza Editorial, 1998.

WERNECK, Humberto et at. A revista no Brasil. São Paulo: Ed. Abril, 2000

WRIGHT, Charles R. Comunicação de massa: uma perspectiva sociológica. Rio de Janeiro: Bloch, 1968. 